\title{
Emerging Green Market as an Opportunity for Green Entrepreneurs and Sustainable Development in India
}

\author{
Sharma NK* and Kushwaha GS
}

MBA, Maulana Azad National Institute of Technology, Management Studies, Bhopal, Madhya Pradesh, India

\begin{abstract}
In recent decades we can see around the business that the things are changing like never before due to technological advancement, change in economy and political influences. It has been also observed in two decades that there is a major shift in consumers taste and preferences. The companies who are continuous monitoring and focusing on these issues are much more successful than the rest. There is a cut throat competition in the market and every company wants to fill the vacuum of the market by providing desired product and services to the consumers. In current market scenario, the studies show that consumers are now health and environment conscious. Perhaps this is the reason, that the concept of green product and green marketing are taking place slowly and steadily in the market. It can be also as an opportunity for those companies, who believe in innovation and redesigning their products and services in ecological manner. It is a perfect time for those entrepreneurs who want to come and be a part of this emerging green market. The purpose of this paper is to aim in general to understand the opportunities for green entrepreneurs in the changing scenario of market shift. The study is based on available literature, various facts and figures, on this issue. It tries to bring a novel study which can be applied in current market scenario. The study is conceptual in nature and validates its findings with the help of a proposed model.
\end{abstract}

Keywords: Green market; Consumer behavior; Environment; Green entrepreneurs; Opportunities; Sustainable development

\section{Introduction}

Change is a very common phenomenon which can be seen anywhere whether it is business, economics or anything. It occurs some times in cyclic way or may be in a random order [1]. In the same way, when we take a look towards consumers, we find that their needs, wants, demands, test and preferences are also changing. This change is not specific to a particular product category but it is in every product segment. There may be several reasons for that such as increasing consumer household income, change in life style and increasing consumer awareness etc. [2]. Among these changes market also need to adopt some changes for its survival and for that there is a need of new product development concept, product redesign, process design, changes in marketing policies etc. A successful business organization always focuses on these changes and implements it into its operations within time. Changing consumer behavior in the market generates a new market which may be seen as a challenge and opportunity both by many organizations. Those organizations that are capable enough to adopt changes and can fulfill the desire of their customers, they take it as an opportunity but there are several organizations who failed to adopt these changes many times. In recent scenario it has been seen that the consumer behavior is taking a shift towards the eco-friendly product which is also called green product [3]. The significant reason behind this change is increasing pressure on human's planet inform of various pollutions and certain other issues caused by these pollutions. Therefore consumer, Government and business organizations are taking this issue seriously around the world. Government is making strict norms and regulations to forbid the problem arises by business organizations, consumers and other sources. Wherein increasing consumer awareness towards environment change their consumption and buying pattern of products [4]. On the other hand business organizations are also finding fruitful results in adopting green practices in their business operations. Among all these development certain concepts are coming in the field of management such as green marketing, green supply chain management, reverse logistics, waste management etc. [5] which not only fulfills the needs of the consumers but also give assurance about the green and clean environment. Every individual want to keep the environment green and clean because they are aware about the consequences, and due to that they seek green products in the market many times [6]. The concept of green marketing came into existence way back in 1980's in United States and European country and the development goes on [7]. Green marketing concept is gaining its popularity across the world as environment is an international issue now days. Green marketing helps in reducing the impact of environmental consequences with the help of fulfilling the demand of the consumer's green need and also creates the demand for the green product [8]. It is also one of the fact that changing consumer's perception towards green products leads to the genesis of green market [9]. Green marketing concept not only fulfills the needs of the consumer but it also participates in the sustainable development in long run. Due to the increasing growth and development of the green market, there are various opportunities are also coming for entrepreneurs around the world. Innovations and new product development are among the important ingredients of the entrepreneurship and can be seen in the green marketing concept [10]. An entrepreneur always focuses on innovative ideas and brings the change in the society and market with the help of their enterprise [11]. Providing safeguard to the environment is a nobel work for the society and the humanity and a good entrepreneur take care of this entire task as he is also responsible for social welfare. We can see around us, many entrepreneurs those who change the concept of businesses in their own way and provided solution for various problems in the society [12]. Change in consumer

${ }^{*}$ Corresponding author: Nagendra Kumar Sharma, MBA, Maulana Azad National Institute of Technology, Management Studies, Bhopal, Madhya Pradesh, India,Tel: +91-9009697291; E-mail: nagendrasharmag@gmail.com.

Recieved March 19, 2014; Accepted April 17, 2015; Published April 24, 2015

Citation: Sharma NK, Kushwaha GS (2015) Emerging Green Market as an Opportunity for Green Entrepreneurs and Sustainable Development in India. J Entrepren Organiz Manag 4: 134. doi:10.4172/2169-026X.1000134

Copyright: @ 2015 Sharma NK, et al. This is an open-access article distributed under the terms of the Creative Commons Attribution License, which permits unrestricted use, distribution, and reproduction in any medium, provided the original author and source are credited. 
buying pattern on the basis of eco-friendly or green product there is a space creation for the green entrepreneurship. Green entrepreneurship innovates, substitutes the traditional or conventional products into the green products and taps the green market. Creation of the green market is a kind of an opportunity for these green entrepreneurs as it is an emerging market and not penetrated enough. These green entrepreneurs are also called enviropreneurs as they build their business which is favorable to the environment and society. The concept of green entrepreneurs is not only helping consumer in getting their green products and services but also make people learn towards greening ecosystem. But green entrepreneurs also face challenges such as lack of substitution of the conventional products, cost controlling, redesigning, raw material and lack of $\mathrm{R} \& \mathrm{D}$ infrastructure etc. These challenges can be reduced in further development. On the other hand it is also true that successful green entrepreneurs create changes in the society in form of providing a good natural environment [13]. Various developed and developing countries are now started adopting green practices such as green marketing, green supply chain and waste management [14] which is a favorable atmosphere for such green entrepreneurs. The nurturing of green entrepreneurs also encourages young graduates to come and be a part of this emerging opportunity. Green entrepreneurs can make profit through the market as well as social recognition in the society. Therefore we can say it is not all about business only but somewhat it is a kind of social activity in terms of providing a safeguard to our natural environment. The paper is trying to focus on how emerging green markets is an opportunity for green entrepreneur and sustainable development in India. The paper is segmented in various parts such as theoretical background of the study i.e. literature review, identification of various parameters on the basis of the literature review, methodology, development of the conceptual model, discussion and findings, managerial implication, conclusion, contribution of the study, limitations and future research scope.

\section{Literature Review}

\section{Environmental issues}

The top ten environmental issues facing our planet is population, climate change, loss of biodiversity, the phosphorus and nitrogen cycle, water, pollution, ozone layer depletion, ocean acidification, over fishing and deforestation (Planet earth herald). Rapid development in the economy which is always works like an indicator of a successful development of a nation is among the major cause of environmental loss [15]. Development of a nation is mainly dependent upon the successful industrial output [16]. But many times the environment gets ruin in the development war by the nations [17]. The increasing pressure on our green planet is continuous going on and human have also started to experience the consequences of the environment in form of various havoc [18]. Issues like global warming, climate change are the part of every news now days. Excessive use of natural resources and dependency on non-renewable energy are the major challenges in front of the human kind [19]. Government and various other agencies are continuously working to provide a better shield to the natural environment and endeavors are going on at international level and on the other hand, sustainable development is key agenda of the Government as it saves our natural resources for meeting the present and future needs [20]. Various committees, NGO's and teams have been formed to control the consequences of the environment and also showing positive results [21]. It is the matter of fact majority of the censure goes to the industries but they are not the only responsible for the creation of environmental problems [7]. Human consumption pattern is also very much responsible in harming the environment as consumption leads to the direct creation of environmental pressure from the use of various products and services as in case of a through car driving burns fossil fuel which is limited resource on the earth The changing income level, life style pattern and their responsiveness towards environment affects our natural ecosystem [2]. Studies also show that awareness and education gives positive approach towards the environment. Environmental issues are one of the major ingredient of many research work as it is directly associated to the existence of human and its planet [22]. It is also true that environmental consequences can be controlled by changing certain consumption behavior of mankind in long term.

\section{Changing consumer behavior towards green products}

Change is a very natural phenomenon of nature and same is applicable for the human. Change in consumer behavior has many reasons such as change in income, life-style and many more [2] but it is also seen that there are certain changes take place in consumer buying attitudes which is based on their knowledge, awareness and education Environmental knowledge also changes the mind of the consumer which can be observed in their purchase intentions towards green products or ecological products [3]. Changing consumer behavior towards green products leads to the increasing demand of it and develops an arena for the green market [23]. Demographic criteria are less significant than the psychographic criteria in case of green consumer purchase behavior [24]. The study also reveals that the demand for green product can be understood as the consumer has the willingness to pay for the high priced product or premium price for it [8]. Environmental concern started in way back 1970 and its importance is increasingly in today's Cenozoic era in context to the sustainability [25]. Green perceived value would positively affect the green trust and green purchase intention, while green perceived risk negatively affect both of them and expectation of green product is often hurt by the perception that these product are low value and failed to fulfill their environmental claims [26]. The problem is generally known as consumer skepticism, which need proper attention in order to eliminate it [9]. There is need of more promising reliable companies those who can make reliable promises related to the green product. As the demand of the environmentally responsible product is increasing and need to remain competitive, has provoked many managers seeking information related to the responsible purchase behavior [27]. There are some adverse findings also which discourages the green marketers also such as consumers environmental concern is not reflected in their purchase behavior ,There may be various causes for it as lack of marketing strategies etc. [9].

\section{Green marketing concepts and philosophies}

Green marketing concept evolve in 1960 when US and Europe has realized the environmental burden and formed agencies like environmental protection agency(EPA) with the objective of becoming green and clean. The ecological pressure was also realized by the business houses and they started greening business. The development goes on and till 1990 it took a proper shape [7]. The American marketing association (AMA) conducted the first workshop on 'ecological marketing' in 1975 . The proceeding of the workshop converted in the form of a book on green marketing entitled "ecological marketing" [28]. It was the evolution phase of green marketing in the field of academia [29]. Green marketing has various synonyms such as 'ecological marketing'; 'sustainable marketing' and 'environmental marketing' [30]. The development of the green marketing is taking place rapidly now days as every organization want to enjoy the 
Citation: Sharma NK, Kushwaha GS (2015) Emerging Green Market as an Opportunity for Green Entrepreneurs and Sustainable Development in India. J Entrepren Organiz Manag 4: 134. doi:10.4172/2169-026X.1000134

competitive advantage and it works [31]. Green marketing not only helps in organizational competitive advantage but also responsible for organizational performance in many cases Organizations are adopting green marketing strategies due to assertive and defensive ways. Young and educated generation is taking very much interest in green products but there are still some obstacles such as substitution of the raw material, process redesign, cost etc. [8]. On the other hand various organizations are working on the reduction of the cost of green product with the help of reverse logistics and green supply chain management so that they can make the product more affordable for the maximum market segment [32]. Automobiles are one of the highest pollutant product segments and therefore green marketing is also taken a better shape around the world and companies like Nissan, GM, Ford, Daimler Chrysler etc. and other car manufacturers are working aggressively in this area. Studies claim that the Green marketing is future of the marketing management [33]. There are various important elements of green marketing, which can be seen in the Table 1.

\section{Genesis and attributes of green entrepreneurs}

The work on the phenomena of environment entrepreneurship had begun in the late 1970 and till 1990 it got the attention. According to the study were the pioneers in the field and began to employ the term 'environmental entrepreneurs', 'green entrepreneurs', 'ecoentrepreneurs' and also derivate as 'eco-preneurs' [29]. The term 'green entrepreneurs' was coined by Terry Clark from Goizueta Business School, Emory University [11]. The term green entrepreneurs are a combination of two word i.e. environment and entrepreneurship. Green entrepreneurs are the formulation and implementation of environmental advantage, corporate strategies and creating revenue. An entrepreneur is someone who produces for the market and he is determined and creative leader always looking for opportunities to improve and expand his business and one of the best innovators. In the same way enviropreneurs are also innovating and participating in the process of sustainable development. Sustainability is the main stream of the business strategy; hence entrepreneurs are the important chain for holding the responsibility towards sustainable society [34,35]. Sustainable entrepreneurs aim to introduce environmentally and socially friendly innovations to a large group of stakeholders [36]. Sustainable entrepreneurship gained force in recent years as a global movement that aims to promote business to pay close consideration to their social and environment [37]. Enviropreneurs are important to the economic development as they are the significant contributors in providing the job and also treated as the driving force towards the change, they also get appreciated for introducing the innovation, adopting and developing new thoughts and responsive towards change in rapid, flexible and efficient than the larger organizations [38]. The nexus of environmental, economic and social objectives creates enviropreneurial strategies which leads to active entrepreneurship and innovation to solve green problems while boosting competition and benefiting society. Enviropreneurial business process and marketing also leads to competitive advantage of the firm [11]. A study reveals three key sociological constructs in green business i.e. personal motivation and mission; locality and a forward thinking which leads to sustainability for long run [38]. On the basis of this study about green entrepreneurs a figure has been developed which is showing the composition of it. It can be seen in Figure 1.

\section{Indian market scenario for entrepreneurs}

There is a good hope from the new Government in India in the development of entrepreneurship. Finance Minister of India has released the budget of 2014-15 and gave focus to the entrepreneurship as for creating a conducive eco-system for the venture capital in MSME's (Micro, Small and medium enterprises) sector Rs.10,000 crore fund to act a catalyst to attract private capital by way of providing equity, quasi equity, soft loans and other risk capital for start-up companies and he also announced a national wide incubation and accelerator program, entrepreneurial friendly legal bankruptcy frame work [39].

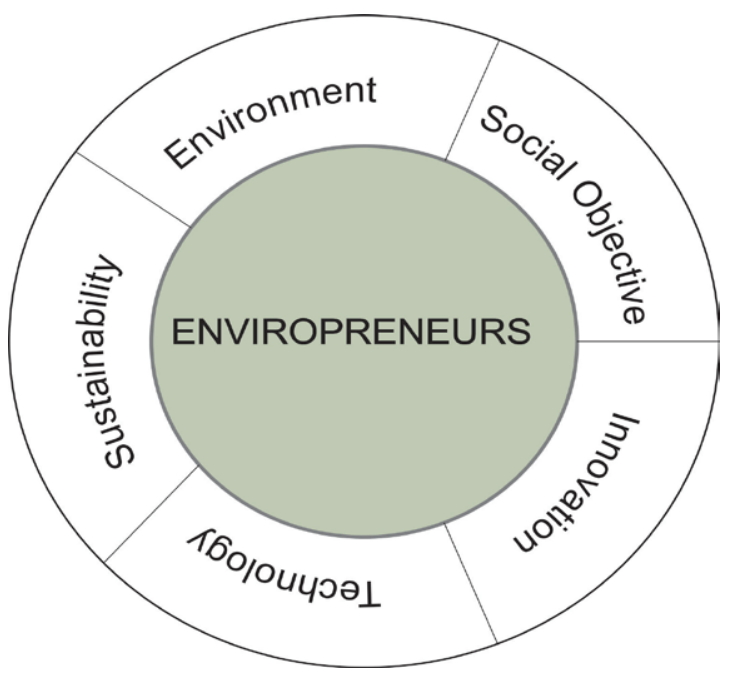

Figure 1: Composition of Enviropreneurs or green entrepreneurs.

\begin{tabular}{|l|l|l|l|}
\hline S.no. & Elements & Descriptions & Authors \\
\hline 1. & Green product & $\begin{array}{l}\text { Those products which are presumed environmentally safe called green } \\
\text { product. It includes redesign and new product development process. }\end{array}$ & $\begin{array}{l}\text { (Polonsky et al., [8]); (Saxena and Khandelwal [3]); } \\
\text { (Chen-Lin et al.,); (Kaur et al., [6]); (Lampe and Gazda } \\
\text { [7]); (Gleim, [9]); (Ilker,); (Singh et al., [14]). }\end{array}$ \\
\hline 2. & Eco-labels & $\begin{array}{l}\text { Eco-labels are the logo or mark on the product which assures or helps in } \\
\text { identifying the green product. }\end{array}$ & Thogersen et al. \\
\hline 3. & Green price & $\begin{array}{l}\text { Green price is also called premium price which is charged by the green } \\
\text { customers that may be extra charge for the green product. }\end{array}$ & Polonsky et al. [8] Gleim et al. [9], \\
\hline 4. & $\begin{array}{l}\text { Green supply chain } \\
\text { management(GSCM) }\end{array}$ & $\begin{array}{l}\text { Green supply chain management starts from the procurement of raw } \\
\text { material and till disposal of the product in a greener manner. }\end{array}$ & (Chen-Lin et al., [6]); Chang, et al..[26]). \\
\hline 5 & Reverse logistics & $\begin{array}{l}\text { Reverse logistic is one of the sub elements of GSCM, which takes the } \\
\text { used product from the customers and send it to the manufacturers again } \\
\text { for recycling. }\end{array}$ & (Polonsky [8]); (Chen [26]); Hazen et al. \\
\hline 6. & Green promotion & Communicating about the green product to the customer. & (Polonsky [8]. \\
\hline 7. & Green positioning & Positioning the green customer segment in long run. & Polonsky [8]. \\
\hline
\end{tabular}

Table 1: Key elements of the green marketing 


\begin{tabular}{|l|l|l|l|}
\hline S.No. & Ingredients & Description & Authors \\
\hline 1. & Environmental issues & $\begin{array}{l}\text { The world is facing crucial time for our natural environment as } \\
\text { it is blighting, which can be experienced by every individuals } \\
\text { in form of various problems like pollutions, global warming, } \\
\text { climate change etc. }\end{array}$ & $\begin{array}{l}\text { (Planet earth herald); (Skaza et al., [17]); (Galli et al., [18]); (Ashley et al.,[19]); (Yarong et al., } \\
\text { [20]); (Jia-nan, [21]); (Christensen et al.,[2]); (Straughan et al.,[4]); } \\
\text { (Sherbinin [22]). }\end{array}$ \\
\hline 2. & Consumer behavior & $\begin{array}{l}\text { Due to the problem arising in our natural environment, people } \\
\text { are aware and changing their consumption behavior and } \\
\text { seeking product and services which are eco-friendly. }\end{array}$ & $\begin{array}{l}\text { (Straugh [4]); (Christensen [2]); (Saxena et al., [3]); (Lin et al. [5]) } \\
\text { (Polonsky et al., [8]);(Chen[6]); (Gleim et al., [9]). }\end{array}$ \\
\hline 3. & Green marketing & $\begin{array}{l}\text { Green marketing is a result of development in changing } \\
\text { consumer behavior pattern towards green products. It profits } \\
\text { to both consumer and marketers. }\end{array}$ & $\begin{array}{l}\text { (Chen et al., [6]); (Polonsky et al., [8]); (Saxena et al., [3]); (Gleimet. } \\
\text { al (Singh et al., [14]); (Lampe et al., [7] 1995); (Henion [28]). }\end{array}$ \\
\hline 4. & $\begin{array}{l}\text { An entrepreneur, who develops green business with the help } \\
\text { of adopting green practices. }\end{array}$ & $\begin{array}{l}\text { (Menon and Menon [11]); (Keskin et al., [10]); (Shepherdal., [13]); } \\
\text { (Dean et al., [35]); (Allen et al., [38]). }\end{array}$ \\
\hline 5. & $\begin{array}{l}\text { Favorable market } \\
\text { condition }\end{array}$ & $\begin{array}{l}\text { Indian market is suitable for entrepreneurs than ever before as } \\
\text { change in Government policies for the entrepreneurs. }\end{array}$ & (Sabharwa et al., [40]). \\
\hline
\end{tabular}

Table 2: Significant ingredients supporting the study.

Indian clean energy sector is a \$US20 billion opportunity. It has the potential to generate $10 \mathrm{mn}$ jobs in India by 2025 and is witnessing the emergence of energy entrepreneurs, who are all set to write new codes in the energy domain [40]. In recent news, Union Bank cuts interest rates in MSME's loans [41]. On the other hand it is also one of the facts that India has the power of young and educated graduates who are vibrant and full of enthusiasm and ready to accept the opportunities of entrepreneurship. The Government is continuous providing better inputs for the business opportunities, which helps these entrepreneurs. The current market condition is favourable for entrepreneurs in country like India. Several agencies are formed for the development of the prospective entrepreneurs which creates a suitable environment.

Indian economy is growing rapidly, and investors from abroad are also keen to invest in Indian market which proofs India is a better place to invest. Government is also focusing on development of better norms for FDI (Foreign direct investment), for attracting investors from abroad. On the basis of the above literature review a table has been formed which identifies the important ingredients for this study and also gives a brief introduction. It can be seen in the Table 2 .

\section{Methodology}

The paper is based on exploratory research and conceptual in nature. The study has been done on the basis of extensive literature review. All the relevant findings of the research papers has been tabulated and summarized which can be seen in the Table 2 which further helps in developing a conceptual framework of the study.

\section{Development of Conceptual Model}

On the basis of the study of literature and identification of various significant ingredients Table 2, a conceptual model has been proposed. Figure 2 represent the conceptual model of the study.

\section{Discussion and findings}

The conceptual framework shows in Figure 1 that the concept of green entrepreneurs starts from the environmental concerns such as pollutions, global warming, climate change, scarcity of natural resources and other havoc caused by disturbance in the ecosystem. Due to increasing awareness may be with the help of environmental knowledge and education people are becoming more responsive towards the environment. These factors are also responsible for the changing consumer behavior towards green product or eco-friendly product. The perception towards green product gives a positive impact on the development of the green market. Green market is an emerging market, which brings ample of opportunities in every field such as greening supply chain, green production, green design and many more. The current market scenario has various opportunities for the entrepreneurs as well as for green entrepreneurs. These opportunities can be also helpful for bringing motivation and empowerment to the green entrepreneurs. The successful green entrepreneurs lead to the sustainable development in long term.

Findings: Study based on the literature survey and conceptual model shows the following major findings of the study:

1. There is a bright opportunities for the green entrepreneurs as the green market is expanding and consumer behavior is favorable towards green market.

2. India is going to be one of the best destinations in the world for the investment point of view.

3. The study found that there is a conceptual link among environmental concern, emerging green market, green entrepreneurs and sustainable development.

\section{Research Implications}

The study findings and discussion of the study would be beneficial for the academicians, research scholars, practitioners, managers and policy makers. The study would be benefited for the academicians and research scholars, as this study gives further insights in this field and there are less numbers of works are available especially in Indian context. Managers and practitioners can understand the opportunities which are emerging in the field of green marketing and there is need of much more focus on it. As it will be profitable and can be significant for sustainable development. Finally the policy makers must more concern on this issue by creating a suitable environment for the green entrepreneurs program.

\section{Conclusion and Recommendation}

On the basis of various explanations in this paper we can understand various opportunities for the green entrepreneurs due to emergence of green market. Changing consumer behavior towards green market is another significant and positive indicator for the green entrepreneurs. Green entrepreneurs or enviropreneurs are not only important just for the fulfilling the need of consumers but they mean more than it. Green entrepreneurs have the responsibility towards achievements of social objectives, economic objectives, environmental objective and sustainable objectives. Green entrepreneurs are the warriors who continuously work, in order to protect the nation from all the evils such as poverty, unemployment and pollution etc. If we think of the 
Citation: Sharma NK, Kushwaha GS (2015) Emerging Green Market as an Opportunity for Green Entrepreneurs and Sustainable Development in India. J Entrepren Organiz Manag 4: 134. doi:10.4172/2169-026X.1000134

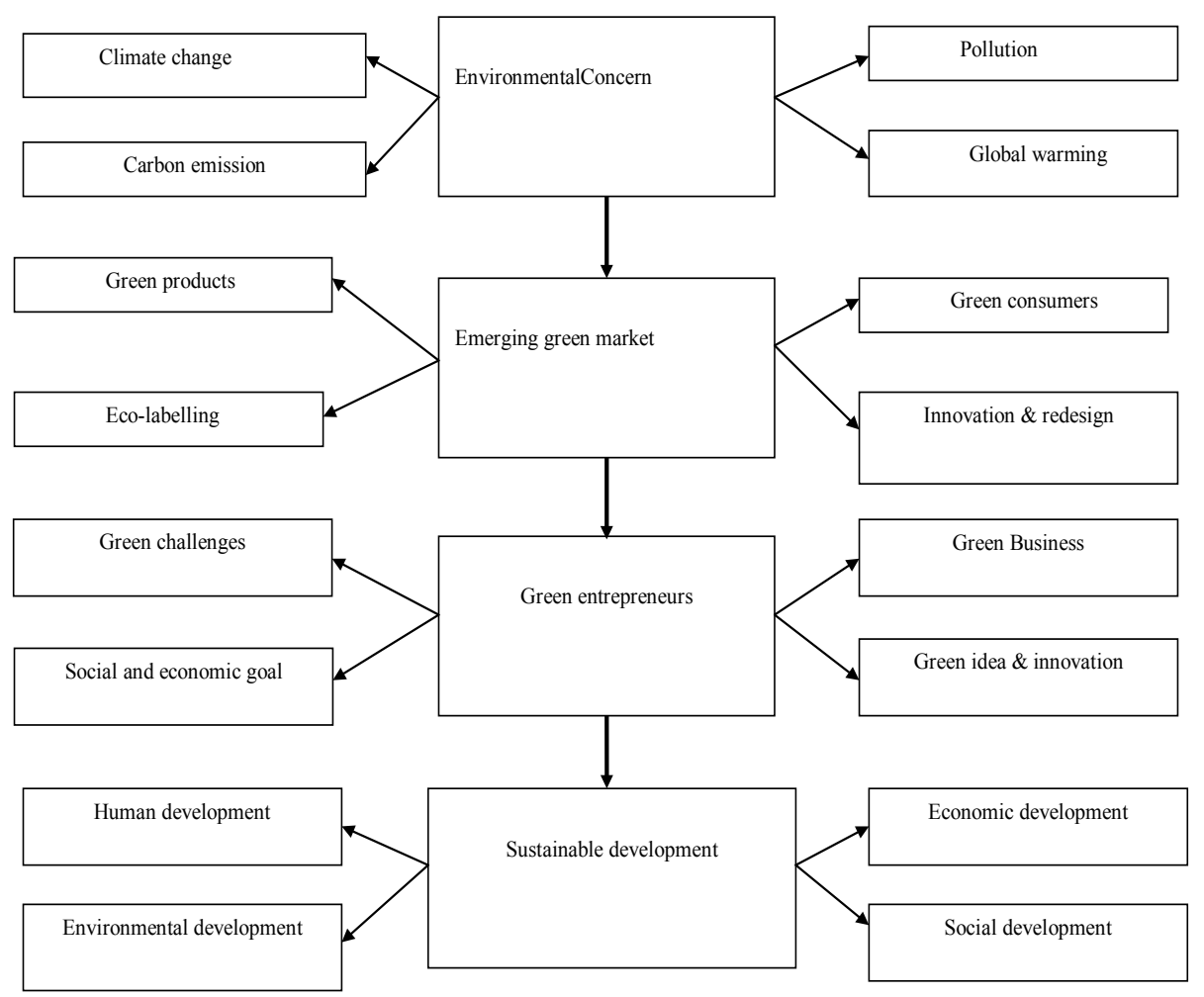

Figure 2: A conceptual model showing nexus among environmental issues, emerging green market, green entrepreneurs and sustainable development.

\begin{tabular}{|l|l|}
\hline S.No. & Name of the enviropreneur/s \\
\hline 1. & Supriya Nikumbh and Bhairavi Shevade \\
\hline 2. & Rajaram Tripathi \\
\hline 3. & Damji Prajapati \\
\hline 4. & Mini \\
\hline 5. & AnupamJalote \\
\hline 6. & Pallavi Agarwal and Prachi Agarwal \\
\hline 7. & Dhivik Reddy \\
\hline 8. & T.S. Sankker \\
\hline 9. & Surendranath \\
\hline 10. & Jos Raphael \\
\hline 11. & Sunil Mehta \\
\hline 12. & Mansukhlal Raghavjibhai Prajapati \\
\hline 13 & Preethi Sukumaran and Sriniwas \\
\hline
\end{tabular}

Name of the organization

Green drops India

Danteshwari herbal products

$-$

MINC retail store

Green oil

Chalk and Chukles

Go Green BOV

Biotec Bags

Uravu, Kerala

Mazhapolima

The tree house resort

Mitti cool clay products

Krya consumer products

\section{Description of business}

Engaged in vertical gardening on walls of the buildings.

Engaged in organic farming and won the "Earth hero" award from Royal bank of Scotland

Making nest for birds made of clay, which can be fixed. Got many projects from real estate sectors.

Eco-friendly fashion store

Production of renewable energy and organic manure from the wate material Manufacturing of toys without use of plastic and chemical based paints.

Electric bikes

Biodegradable plastic bags

Making of houses and handicrafts of bamboo.

Techniques of water harvesting

Providing natural habitat to exotic birds

Fridge made of clay

Chemical free detergent etc.

Table 3: List of few Indian enviropreneurs and their green business

traditional entrepreneurs they have also big responsibility on their shoulders but green entrepreneurs have some more responsibility that is adoption of green practices and other environmental tasks. India is a country of young people. Our majority of the youth are getting good education and thousands of young generations are getting graduate each year. This means that India has great potential towards green entrepreneurship. In India most of the entrepreneurs are young and their concept of business is unique and somewhere they implement the practical aspects of their education in their businesses and getting a great success. The concept of green entrepreneurs is not different, the one who more innovate green product or services more he become a successful green entrepreneurs. Although it is difficult to innovate green products many times as it is difficult to provide substitutes for various raw materials, this is a kind of challenge which a green entrepreneur can handle. There are several examples of green entrepreneurs who are continuously involved in the green businesses. Following is the list of few green entrepreneurs who are engaged in green business or green marketing. The information has been taken from the article published on yourstory.com and India today.in and further tabulated in Table 3.

\section{List of few Indian enviropreneurs and their green business}

Change in purchase intentions or behavior has given space for these 
Citation: Sharma NK, Kushwaha GS (2015) Emerging Green Market as an Opportunity for Green Entrepreneurs and Sustainable Development in India. J Entrepren Organiz Manag 4: 134. doi:10.4172/2169-026X.1000134

green entrepreneurs and the concept is welcomed by many customers and they are also gaining money and fame for the economic and social cause. But it can be observed that still there are less numbers of green entrepreneurs in the country, which can be increased with the help of change in Government policies and support, such as tax exemption, infrastructural facilities, training programs and other motivational schemes for green entrepreneurs. Finally it can be said that, Government of India is also suitable for the entrepreneurs and change in consumer behavior towards green market has created a better opportunity for these enviropreneurs. The new policies regarding "Make in India" will be promising the entrepreneurs in Indian scenario. Make in India and make it green will double the interest of the investors and Government.

\section{Contribution of the Study}

Before planning this paper we have reviewed various research papers in reputed journals but none of the study was completely based on such kind of issue even though in Indian scenario, and which shows a research gap between consumer behavior and green entrepreneurs. Therefore in order to bridge the gap this study has been propounded on this issue and would surely help in this discipline.

\section{Limitations and Further Research}

Every study has their own limitations same as in this study. There is lack of good studies which is relevant to this paper especially in context to consumer behavior, green marketing and the enviropreneurs. This paper can be a base for further research and one can make an empirical research paper by using the concept and various identified parameters of this study. Although the concept is not very new but needs proper attention by researcher as the issue is very important for our economy and environment both. There are still many things may be left in this paper which can be added in the further research work.

\section{References}

1. Zarnowitz $\mathrm{V}$ Moore $\mathrm{GH}$ (1986) Major changes in cyclical behavior, UMI: 519-582.

2. Christensen $P$ (1997) Different lifestyles and their impact on the environment. Sustainable development 5: 30-35.

3. Saxena RP, Khandelwal PK (2008) Consumer attitudes towards green marketing on exploratory study. University of Wollongong Research Online 1-31.

4. Straughan R, Roberts J (1999) Environmental segmentation alternatives: a look at green consumer behavior in the new millennium. Journal of consumer marketing 16: 558-575.

5. Chen YS, Lin CL, Chang CH (2013) The influence of green wash on green word-of-mouth (green WOM): the mediation effects of green perceived quality and green satisfaction. Quality and Quantity 48: 2411-2425.

6. Pavleen K, Raghbir S (2006) Children in family purchase decision making in India and the West: A review, Academy of Marketing Science Review.

7. Lampe M, Gazda GM (1995) Green marketing in Europe and the United States: An Evolving Business and Society Interface. International Business Review 4: 295-312.

8. Polonsky MJ, Rosenberger PJ (2001) Reevaluating Green Marketing: A strategic approach. Business Horizon 21-30.

9. Gleim MR (2013) Against the Green: A Multi-method Examination of the Barriers to Green Consumption. Journal of Retailing 89: 44-61.

10. Keskin D, Diehl JC, Molenaar N (2013) Innovation process of new ventures driven by sustainability. Journal of Cleaner Production 45: 50-60.

11. Menon A, Menon A (1997) Enviropreneurial Marketing Strategy: The Emergence of Corporate Environmentalism as Market Strategy. Journal of Marketing 61: 51-67.

12. Green warriors: Entrepreneurs and Innovators inspire change with eco-friendly business ideas, India today (n.d).
13. Shepherd A, Patzelt $H$ (2011) The new field of sustainable entrepreneurship studying entrepreneurial action Linking? What is to be sustained? With? What is to be developed? Entrepreneurs Theory and Practices 35: 137-163.

14. Singh PB, Pandey KK (2012) Green Marketing: Policies and Practices fo sustainable development. Integral Review- A Journal of Management 5: 22-30

15. Skaza J, Blais B (2013) The Relationship between Economic Growth and Environmental Degradation: exploring Models and Questioning the Existence of an Environmental Kuznets Curve. working paper series, The central for global and regional economic studies at Bryant University, USA.

16. Gelb A (2010) Confronting Old and New Challenges organized by the Central Bank of Algeria and the IMF Institute in Algiers.

17. Lakshmana CM (2013) Population, development, and environment in India Chinese Journal of Population Resources and Environment 11: 367-374.

18. Galli A, Wiedmannb T, Ercinc E, Knoblauchd D, Ewinge B, et al. (2012) Integrating Ecological, Carbon and Water footprint into a "Footprint Family" of indicators: Definition and role in tracking human pressure on the planet. Ecological Indicators 16: 100-112.

19. Ashley M, Bookman J ( 2009) Forms of Energy, earth day network every day for everybody, Washington DC 1-22.

20. Yaronga Z, Xin $Y$ (2011) Research on the sustainable development and the objective of Chinese Government performance audit. Energy Procedia 5: 1230 1236.

21. Jia-nan C (2012) Contributions of Environmental NGO to Environmental Education in China. IERI Procedia 2: 901-906.

22. Sherbinin AD, Carr D, Cassels S, Jiang L (2009) Population and environment Annual Review Environment Resource 32: 345-373.

23. Lin RJ, Tan KH, Geng Y (2013) Market demand, green product innovation, and firm performance:evidence from Vietnam motorcycle industry. Journal of Cleaner Production 40: 101-107.

24. Paco AD, Raposo M (2009) Green segmentation: An application to the Portuguese consumer market. Market Intelligence and Planning 27: 364-379.

25. Royne MB, Levy M, Martinez J (2011) The Public Health Implications of Consumers' Environmental Concern and Their Willingness to Pay for an EcoFriendly Product. The Journal of Consumer Affairs 45: 329-343.

26. ChenYS, Chang CH (2012) Enhance green purchase intentions The roles of green perceived value, green perceived risk, and green trust. Management Decision 50: 502-520.

27. Follows SB, Jobber D (2000) Environmentally responsible purchase behaviora test of a consumer model, European journal of marketing 34: 723-746

28. Henion KE, Kinnear TC (1976) Ecological marketing. American Marketing Association p: 168

29. Schaper M (2002) The essence of ecopreneurship. Green marketing international 38: 26-30.

30. Pride WM, Ferrell OC (1993) Marketing: Concepts and strategies ( $8^{\text {th }}$ ed.) Boston: Houghton Mifflin

31. Bolivar-Ramos MT, Garcia-Morales VJ, Garcia-Sanchez E (2012) Technological distinctive competencies and organizational learning's: effects on organizational innovation to improve firm performance. Journal of engineering and technology management 29: 331-357.

32. Olugu EU, Wong KY, Shaharoun AM (2011) Development of key performance measures for the automobile green supply chain. Resource, conservation and recycling 55: 567-579.

33. Brecard D (2011) Environmental tax in a green market. Environment Resource Economics 49: 387-403.

34. Hall JK, Daneke GA, Lenox M (2010) Sustainable development and entrepreneurship: past contributions and future directions. Journal of Business Venture 25: 439-448.

35. Dean TJ, Mc Mullen JS (2007) Toward a theory of sustainable entrepreneurship: reducing environmental degradation through entrepreneurial action. Journal of Business Venture 22: 50-76.

36. Zu L (2014) International perspective on sustainable entrepreneurship. Sustainable Entrepreneurship, Business Success through Sustainability 
Citation: Sharma NK, Kushwaha GS (2015) Emerging Green Market as an Opportunity for Green Entrepreneurs and Sustainable Development in India. J Entrepren Organiz Manag 4: 134. doi:10.4172/2169-026X.1000134

Page 7 of 7

\section{7-100.}

37. Farinelli F, Bottini M, Akkoyunlu S, Aern P (2011) Green entrepreneurship: the missing link towards a greener economy. ATDF J 8: 42-48.

38. Allen JC, Malin S (2008) Green entrepreneurship: a method for managing natural resources? Soc Nat Resour 21: 828-844.
39. Sathish K (2014) India Budget, A Boost to Entrepreneurship. National Entrepreneurship Network Bengaluru, Karnataka, India.

40. Sabharwa IP (2012) Power (full) entrepreneurs, Entrepreneurlndia.

41. Parmar B (2014) Union Bank cuts interest rate on MSME loans. Business line The Hindu. 